AMERICAN JOURNAL OF SOCIAL AND MANAGEMENT SCIENCES

ISSN Print: 2156-1540, ISSN Online: 2151-1559, doi:10.5251/ajsms.2012.3.3.106.111

(C) 2012, ScienceHuß, http://www.scihub.org/AJSMS

\title{
The sources and schools of Islamic jurisprudence
}

\author{
Etim E. Okon Ph.D. \\ Department of Religious/Cultural Studies, University of Calabar - Nigeria
}

\begin{abstract}
Islamic jurisprudence is based on divine authority. It cannot be subjected to any precedent from the existing legal systems of the world. Islamic law is considered to be superior to every other legal system in the world, and can neither be influenced, nor persuaded by their rulings. The peculiar jurisdiction of Islamic law is applicable in an Islamic state and is binding on all Muslims. The law is the compass to eternal life and the basis for interpersonal relationship. In this study we shall analyse the sources and schools of Islamic jurisprudence.
\end{abstract}

\section{INTRODUCTION}

Islamic jurisprudence came into existence as an attempt to codify a legal system that will integrate the ethical principles enunciated in the Quran and the sunnah of the Prophet. It faced opposition from the existing legal procedures and, jurists put up strong resistance against the prescriptions of Islamic law. It was al-Shafi'i who introduced drastic remedies in the ninth century A.D to resolve the conflict permanently. Al-Shafi'i admitted that the substantive legal material in the Quran was inadequate, but insisted that the Quran actually indicated the procedure to supplement and interprete difficult legal problems.

Al-Shafi'i built the entire edifice of Islamic law on the Quranic injunction "obey God and His Prophet". To that extent, al-Shafi' $i$ made the Traditions of the Prophet the second authentic source of Islamic law after the Quran. Al-Shafi'i unified Islamic law and made it a coherent principle to be followed by all schools. From that time henceforth all the schools of law in Islam recognized only one sunnah, which consisted of the practice the Prophet followed and its precedents. Al-Shafi'i's codification of Islamic law, brought victory to the traditionists over the jurists. The implication was that the sunnah of the Prophet assumed paramount importance over and above human ratiocination, which became subsidiary and complementary (Savory 56,57).

Sources of Islamic law: Islamic jurisprudence is derived from four sources- the Quran, the hadith, the ijma and the qiyas. We shall now analyze each of the sources seriatim:

The Quran: The Quran which is the word of God as revealed to Prophet Muhammad is the first and supreme source of Islamic law. The word Quran is derived from the Arabic verb qara'a, which means 'to read' or 'to recite'. Another semantic root is the syriac word qeryana, which is also interpreted as 'reading'. The word Quran literally does not mean a book; rather it means revelation, either in part, or the whole. For Muslims, Quran is the greatest theophany which culminated in the earthly reproduction of an uncreated and eternal message of Allah (The New Encyclopaedia Britannica 342).

In Islamic legal system, the Holy Quran is Al-Burhan (the proof), and Al-Furqan (the discernment or distinction). It is discernment and unveiling of the truth. "Truth has come and error (el-batil, the empty, or the inconsistent has vanished away), verily error is ephemeral" (Surah 27: 73). And in Surah 21: 18, it is written: "... We $(A l l a h)$ strike error with truth that it may be crushed, and lo! error vanisheth away" (Surah 21: 18).

In Surah 75: 22, the Holy Quran addresses itself as al-awh al-mahfuz, meaning 'the well-preserved tablet'. Quran is said to be a 'wonder' and a 'miracle'. In its Arabic form, Quran is said to be infallible, unsurpassable in purity, style and content. On the correlation between the Quran and the shariah Doi writes:" It presents clearly the intellectual and moral bases of the Islamic shariah and strengthens them with arguments and appeals to the heart. It clearly defines and limits the bounds of every aspects of life" (4).

The Holy Quran is divided into 30 portions (juz, plural ajza), to ease the process of recitation during the holy month of Ramadan. There are 114 chapters, called surah's. Quranic verses are called ayah (pural ayat, literally 'signs'). The Holy Quran was revealed to Prophet Muhammad in separate pieces, at different times, and places over a period of approximately 20 
to 22 years. Verses in the Quran are not arranged in a chronological order. Prophet Muhammad received the revelation from angel Gabriel while in a trance, and had them written down on pieces of paper, stones, palm leaves, shoulder-blades, ribs, and bits of leather (The New Encyclopaedia Britannica 343).

Of the entire 114 chapters of the Quran, only eighty verses can be considered as legal prescriptions. The Holy Quran was compiled after the death of Prophet Muhammad. It was compiled after the battle of Yamamah in 633 when many Muslims who knew the Quran by heart died. There was fear that knowledge of the Quran might vanish from the earth. Revelations were collected from all available written sources and also from the heart and memories of the faithful (The New Encyclopaedia Britannica 343).

The Hadith: The second source of Islamic law is the hadith (the traditions) of Prophet Muhammad. Traditions were colleted many years after the death of Muhammad. Traditions consist of the deeds, utterances and silent approval of the Prophets. It also applies to the actions or sayings of any of the prophet's companion or their immediate successors. As a legal document in shariah courts, hadith is a compilation and interpretation of the custom or usage of the earliest believers of Islam. It is also called the sunnah of the prophet. The companions and contemporaries of the prophet were called the sahabah. It must be emphasized that tradition has a matter of record and history is called hadith; as a matter of religious obligation, and as a case law, it is called the sunnah of the Prophet.

The ljma: Whenever there is need for the shariah court to determine both the ratio decidendi and res judicata of any suit outside the expressed provisions of the Holy Quran and the hadith, the most reliable and time-honoured option is application of ijma. ljma according to Doi means "the agreed view of the sahaba or the companions of the Holy Prophet of Islam, and later it meant the unanimous consent of the learned doctors" (5). In Islamic case law, consensus is based on collective opinion and unanimous consent of the mujtahidun (Muslim divines of the highest degree of learning). The mujtahidun are expected to be men who have blended scholarship with piety and not heretics.

There were situations where appropriate traditions could not be found to back up the abrogation of some traditional practices of pre-Islamic days and the logical option was to acknowledge their legality through the application of ijma. ljma did not have any general enforcement and acceptance. At Medina, it was only recognized as the consensus of the citizens of Medina. Under the Abbasids, ijma was manipulated and abused as a platform of gaining fealty for the caliphs. It was also used to gain legal recognition for the six canonical books as authoritative and binding sources on the sunnah and hadith of prophet Muhammad.

The popularity and historic acceptance of consensus as a legal option is attributed to the sayings of Prophet Muhammad "my people will never agree upon an error" (qtd. in Savory 57). In Islam, truth is safe within the community. Cragg has commented on the preference and pre-eminence of community view in Islamic law: "consensus means that Islam is what Muslims define it to be... it means that there is a source of security in the communal mind. The Muslim community is not likely to go long, or far, into a position that is not validly Islamic" $(132,133)$.

Judicial decisions based on consensus must have a complementary support from acceptable documentary sources; otherwise, it will be a nullity. Consensus enhances the principle of development to the extent that a new idea with popular communal endorsement could gather momentum as a law, and eventually metamorphosed into a "revelatory" status.

The implication as Cragg rightly observed is that, after God and the Prophet, the community (the ummah) is a powerful source of Islamic jurisprudence: "They, in whose custody of worship and conduct the truths of the religion have been entrusted, may be reasonably accepted as a frame of reference, a court of appeal, for the validation, or otherwise, of what is truly and authentically Islamic" (133). It must be pointed out that consensus is not arrived at through a democratic process. The opinion of the community is not determined democratically through the views of the majority, but the conscious realization of the common will on a particular issue.

The Qiyas: Whenever there is an issue that was not covered by a direct instruction in the Quran or the hadith, Islamic jurists and theologians will apply qiyas which means analogical deduction. "Qiyas means the application to a new problem of the principles underlying an existing decision on some other point which could be regarded with the new problem" (Doi 6).Farah has also defined qiyas as"... the way a belief or practice gains official credence and support on grounds that it is similar to a practice or belief clearly embodied in the Quran, sunnah or ijma" (Farah 187). 
Before the introduction of qiyas, Muslims jurist applied ra'y that is private opinion. It was the attempt to use private opinion in delicate area of religion that qiyas succeeded ra'y as an alternative. The introduction of qiyas, erupted a heated controversy among Muslims theologians and jurist. It was argued that qiyas should be restricted to the area of "material similarity", while others preferred its application only in the area of similarity in motive or cause that were not properly defined.

The acceptance of ra'y in some quarters although it was a product of ijitihad (individual interpretation), was the absence of agreement among the mujtahids, who endorsed individual interpretation. Despite the obvious limitations of qiyas in the achievement of a uniform consensus, it contributed to the progressive development of the ummah into spiritual and moral upliftment. The method of logical deduction and analogical extrapolation was introduced into Islamic jurisprudence so that justice could be achieved through modern hindsight. Analogical or enthymematic direct deduction is called qiyas.

Qiyas is the extension of Islamic law on the basis of a likeness in two situations. The objective or the ideal law must be derived either from the Quran or the hadith, while the analogous case is inferred from the known principles. Cragg has this to say: "... if the Quran prohibits the use of wine, the prohibition might be understood to include other intoxicants that had similar effects, their avoidance also being presumably the intention of the prohibition" (132). Doi gives another explanation in the application of analogy in Islamic jurisprudence: "... wine drinking is forbidden in the Quran under the general term khamar which means anything intoxicating. It is therefore evident that opium and all intoxicating drugs are also forbidden" (7). John Farrar and Anthony Dugdale have this to say on the application of analogy to judicial reasoning in the English legal system: "It rests not just on the number of attributes or relations, which are found to exist in common, but also, and more particularly on the relevance and importance of such attributes or relations" (87).

The ljtihad and other judicial discretions: As a way to resolve the problems and controversies, which the application of consensus and analogy has posed, Islamic jurists developed the principles of ijtihad as a vehicle to ijma. litihad technically means 'enterprise' or 'initiative'. It requires mental alertness and ingenuity to comprehend and identify the right decision in a complex situation. As a method aimed at filling the lacunae in Islamic jurisprudence, judges are only qualified to use this method after intensive training and cognate experience in Shariah bench.

Other judicial options for the interpretation of shariah included ra'y which means expert private opinion. There is also istihsan (Juristic preference), or maslahah (juristic analysis of the commonweal), magasid al-Shariah (interpretation of the general purposes of the law). Another viable and commonly used option is istislah, in which judicial reasonings are based on logical soundness and clarity, not on the basis of consensus, but in the interest of public good. There is also istishab, in which decisions are based on analogical reasoning with a concomitant validation and linkage with the provision of the Holy Quran or the hadith.

Schools of law in Islam (Madahahib): Sorting and verification of thousands of traditions took place in the latter part of the third Islamic century. Within this period six collections were canonized by the Sunni Muslims. An outstanding canon was the Sahih (The Verified) of al-Bukhari, who spent sixteen years visiting Muslim enclaves to collect over 600.00 hadiths, and only included 4.000 in Kitab al-Jami alsahih. The madahahib (sing. madhab: juridicalreligious rite), were given the duty to reduce the sunnah to practical use. While ijtihad kept Islam abreast of social and political upheavals, madhahib guided the faithful in the fulfillment of religious obligations.

Law enforcement in the Islamic community was the prerogative of civil and military officials of the caliphs. The laws which were secular did not have any element of universality either in the content, interpretation or jurisdiction. It varied from one community to another as it incorporated local laws. In Syria, it was influenced by Syro-Byzantine laws, which the ummayads adopted in their caliphate. In areas where Persian culture once dominated, it was influenced by the relics of the sasanid laws, which survived the Islamic invasion. In Jahiliyah Arabia, customary practices survived under Islam in the issues the shariah did not provide specific solutions.

It was only in the third Muslim century that Islamic jurisprudence was categorized into four madhahib. Each madhahib incorporated the norms prevalent in the geographical region where the madhab had predominant followers. The four madhahib are in agreement on all issues that are relevant to Islam as a socio-religious force. The authority, finality and sufficiency of the Quran and hadith as the ultimate 
law for Islam are accepted by the four schools of Islamic jurisprudence.

Historic Islam relies upon four schools of law. The most famous and indeed the largest is that of $\mathrm{Abu}$ Hanifa Numan bin Thabit, who was born at Basra in the year 80 A. H (699 A D). From childhood, Hanifa showed convincing signs of greatness, ingenuity and spiritual devotion. He studied under great Islamic scholars like Hammad bin Abi Sulayman and 'Ata' bin Abi Rabah. With the demise of Hammad, Hanifa emerged as the most authoritative Islamic scholar in Kufa. He attracted a large crowd of students from all parts of the Islamic world who came to study Figh at his feet (Doi 9).

Abu Hanifa's contribution to Islamic jurisprudence was in the area of theoretical systematization of technical legal thought. Since he deliberately refused to hold any public appointment under the Khalifa, he had the liberty and will power to decide cases objectively without fear or favour. Hanifa's legal reasoning and conclusions were dominated by intensive ratiocination and epistemological fortification of the highest category. He relied on his personal judgement (ra'y) and analogy (qiyas). Hanifa's ratio decidendi was based on Quranic, rather than rational proofs. His legal reasoning reflected the views of Iraqi jurists and he was less rigid in the doctrinal interpretations compared to others.

Hanifa after a long period of incarceration, torture and dehumanization by Al-Mansur, the Abbasid Caliph died in prison in Baghdad in $150 \mathrm{~A} \mathrm{H}$ (767 A D), at the age of seventy and was buried at $A^{\prime}$ Zamiyya. The school of law named after him is called Hanfite School. He is known in the Hanfite School of Figh as Imam al-A'zam (the great Imam). There are over 343 million followers of the Hanfite School of Figh, mostly concentrated in Turkey, Pakistan, Afghanistan, China and Russia.

The second most popular and influential school of Figh was founded by Imam Malik whose full name was Abu 'Abd-Allah Malik bin Anas. Malik was born at Medina in the year $93 \mathrm{AH}$ (713 AD). His early childhood was spent at Medina. He studied under the celebrated doyen of Islamic scholarship - Rabi'a bin Farrukh. Malik's biographers attested to the fact that he studied under about 900 teachers out of whom 300 were from the Tabi'un, that is, eminent and distinguished successors of sahaba, the companions of the Prophet Muhammad. Malik also transmitted the traditions with 95 Shuyukh (the learned scholars).
The school of law that is named after him is called the Maliki School. Malik canonized every tradition that guided legal reasoning and decision, and clearly illustrated the correlation between the law and religion in Islam. Law according to him was revealed to Muhammad as the will of God for the benefit of humanity. God is the sole head, and law maker of the Islamic community. For that reason, violation of the law is not only an infringement of the normative principles of the social order, but a wilful, deliberate act of disobedience and rebellion ( $\sin$ ), against the creator and owner of the universe, which attract a penalty (Farah 185,186).

The Malaki reflected the views and practices of Medina; Malik compiled his decisions into the corpus call the Kitab al-Muwatta (the Leveled Path) which was a comprehensive study of law and justice, ritual and practice of Islam according to the ijma. The jurists of Medina depended more on the traditions associated with the companions of Muhammad than with the Prophet himself (Farah 190). Where there was a conflicting tradition, Malik and his followers made arbitrary choice "if for instance the conflict was between a tradition attributed to the Prophet and another to one of his companions, they chose the companion's" (Farah 190).

He was known for courage, objectivity and fearlessness. In one of his judgement (Fatawa), Malik ruled that paying homage to the Abbasid Caliph alMansur was not a binding duty since it was voluntary. Malik is mostly remembered for his doctrine of ijma (consensus). He also fused the customs of Medina into Islamic jurisprudence. He died in the year 179 $\mathrm{AH}$ at Medina, at the age of 85 and was buried in AlBaqi. The Maliki School of Islamic law is concentrated in North Africa and northern Nigeria. There are approximately over 47 million followers of Malik School worldwide.

The third school of law in Islam was founded by Muhammad bin Idris al-Shafi'i who was born at Askalon in Palestine in $150 \mathrm{AH}$ (767 AD). Like Prophet Muhammad, he came from the Quraish tribe. He was known as Imam al-Muttalabi because he was a descendant of the prophet's grandfather, Abd alMattalib. Al-Shafi'i was exceptionally brilliant from childhood. He was naturally blessed with a sharp and retentive memory, such that at the tender age of seven, he learnt the whole Quran meticulously.

At the age of ten, he memorized Kitab al-Muwatta of Imam Malik, and was made a Mufti at the age of fifteen. His early childhood education was at Gaza, 
Palestine. In 195 A.H, he delivered a lecture on the science of hadith in Baghdad. He traveled from Baghdad to Mecca on a Pilgrimage and from there proceeded to Egypt where he was privileged to meet Imam Malik bin Anas. He lived on in Egypt, fully occupied in writing, research and teaching.

Al-Shafi'i's greatest contribution was his ability to reduce the science of jurisprudence into a regular system through the collection of traditions. His favoured pupil and by far his human legacy and replica Imam Ahmad bin Hanbal wrote: "Until the time of al-Shafi'i, men did not know how to distinguish between the traditions that were in force and those that were cancelled" (qtd. in Doi 11). The most outstanding principle of al-Shafi'i and his followers was that any tradition that did not sustain the Prophet's authority was not legally binding on the Islamic community. The Malikis and Hanafis accepted as binding the traditions of companions and their followers (al-Tabi'un), if it was in conformity with the prevalent norms of the host community.

It was al-Shafi'i who for the first time defined the components of shariah law as consisting of: (1) Quran, (2) sunnah, (3) ijma, and (4) qiyas, and also downgraded the use of ra'y to secondary importance. Al-Shafi'i established the principle that no tradition directly linked to the Prophet could be superseded, it was his considered opinion that an authentic tradition from the Prophet invalidates any tradition attributed to the companions or their followers, when there is a conflict of interpretation. Al-Shafi'i elevated the authority of hadith to a superlative source of Islamic law. He insisted that "God had made obedience to the Prophet incumbent on all believers, and therefore what he said came from God as the Quran did" (qtd. in Farah 192). Al-Shafi'i's followers worldwide are approximately over 102 million and are found in Palestine, Lebanon, Egypt, Iraq, Saudi Arabia, Yemen, Malaysia and Indonesia (Doi 11).

The fourth school of Islamic jurisprudence was founded by Imam Ahmad who was born in $164 \mathrm{~A} \mathrm{H}$ (780 A D). Imam Ahmad studied jurisprudence, hadith and lexicography at Baghdad. His most outstanding teachers included, Yazid bin Harun and Yahya bin Sa'id. He also had the privileged to listen to Imam al-shafi'i in $195 \mathrm{AH}$ in a public lecture on hadith in Baghdad. Ahmad had a profound knowledge of both spiritual and civil law.

When the argument whether Quran was created or it existed from eternity erupted, Caliph Mu'tasim-Billah of the Abbasid dynasty, was of the opinion that it was created. Imam Ahmad insisted authoritatively that Quran was not created, and that it existed from eternity. This led to his incarceration and physical torture for a long time. He regained his freedom when Caliph Mutawakkil announced a general amnesty, leaving individual Muslims to decide for themselves the correct answer. Imam Ahmad came out of prison and was given an official reception in Caliph's court with a generous gift of 1,000 pieces of gold, which Ahmad courageously rejected.

\section{CONCLUSION}

Law as a social institution is dynamic. It is in the interest of society for the law to be subjected to comprehensive reforms to accommodate the positive dimensions of social change. All over the world, there is a mounting pressure for the review of Islamic law. Islamic law is accused of rigidity and conservatism. The world has changed and it doesn't make sense to uphold out-dated legal principles in the $21^{\text {st }}$ century. The law cannot be static in modern society. Presently, the struggle for revisionism is gathering momentum internally within Islam. Islam does not have any reason to appear obsolete. The option for Islamic law, theology and philosophy is to recognise change and its impact on a religion.

\section{WORKS CITED}

Adams, Charles J. "Islamic Faith" in Introduction to Islamic Civilization, (ed) R.M. Savory, Cambridge: Cambridge UP, 1976.

Al Faruqi, Ishmail R. Humanism and the Law: The Case of the Shariah, Nigerian Institute of Advanced Legal Studies, 1991.

Anderson, Norman. The World's Religions, Grand Rapids, Michigan: Eerdmans, 1976.

Brown, Robert Mcafee, Religion and Violence, Philadelphia: Westminster, 1973.

Cragg, Kenneth, The Call of the Minaret, Maryknoll, New York: Orbis, 1985.

Doi, A.R.I, The Cardinal Principles of Islam, Zariah: Hudahuda, 1981.

Farah, Caesar E. Islam, Woodbury, New York; Barron, 1970.

Farrar, John $\mathrm{H}$ and Anthony $\mathrm{M}$. Dugdale, Introduction to Legal Method, London: Sweet and Maxwell, 1990.

Guillaume, Alfred, Islam, London: Penguin, 1954.

Kalu, Ogbu, "Religion as a Factor in National Development" in Readings in Social Sciences, E. C. Amucheazi (ed.) Enugu: Fourth Dimension, 1980, 307-319. 
Am. J. Soc. Mgmt. Sci., 2012, 3(3): 106-111

Maududi, Sayyid Abul' Ala. Towards Understanding Islam, Riyadh: WAMY, 1960.

Saiedi, Nader "What is Islamic Fundamentalism" in Prophetic Religions and Politics: Religion and the Political Order, vol.1, Jeffrey K. Hadden and Anson Shupe (ed.), New York: Paragon, 1984, 173-195.
Savory, R.M, (ed.) Introduction to Islamic Civilization, London: Cambridge UP, 1976, 54-60.

"Quran" in The New Encyclopaedia Britannica, Macropaedia vol. 15, 1975, 341-345. 